[RAdiocarbon, Vol 26, No. 3, 1984, P 367-383]

\title{
HAMBURG UNIVERSITY RADIOCARBON DATES IV
}

\section{H W SCHARPENSEEL, HEINRICH SCHIFFMANN, and PETER BECKER}

Ordinariat für Bodenkunde der Universität Hamburg Allendeplatz 2, 2000 Hamburg 13, West Germany

This list consists of dates of soil samples from selected soil profiles in Tunisia, Sudan, and Argentina. The profiles from Tunisia were taken to elucidate ages of typic paleosols of paleoclimatic significance. The Sudan profiles increase our understanding of pedogenesis of Sudanese Vertisols. The existence of pedoturbation in these profiles is further explored and questioned. The profiles of Argentina were dated to supplement information from chemical and micromorphological studies.

\section{ACKNOWLEDGMENTS}

This work was supported by the Deutsche Forschungsgemeinschaft.

\section{SAMPLE DESCRIPTIONS}

SOIL SAMPLES

Pretreatment of soil samples is described by Scharpenseel and Pietig (1969) and Scharpenseel (1972; 1977).

\section{Tunisia}

Dates are from genetic horizons or layers of soil largely characteristic of paleosols throughout Tunisia.

HAM-1029.

$2420 \pm 70$

Fossil gyttja, $12 \mathrm{~km} \mathrm{NW}$ of Degache, Chott el Rharsa $\left(34^{\circ} 5^{\prime} \mathrm{N}, 8^{\circ}\right.$ $\left.11^{\prime} \mathrm{E}\right), 68 \mathrm{~cm}$ depth.

HAM-1030.

Paleargid near Algerian border $\left(33^{\circ} 50^{\prime} \mathrm{N}, 7^{\circ} 43^{\prime} \mathrm{E}\right)$, underlying fringes of dunes, 70 to $80 \mathrm{~cm}$ depth.

HAM-1031.

$8050 \pm 100$

Oued Lakarit $\left(34^{\circ} 3^{\prime} \mathrm{N}, 10^{\circ} 2^{\prime} \mathrm{E}\right)$, fA overlying fBt, $250 \mathrm{~cm}$ depth.

\section{HAM-1032.}

$\mathbf{3 4 7 0} \pm \mathbf{7 0}$

Buried Argixeroll, $12 \mathrm{~km}$ before Ksour Essaf $\left(35^{\circ} 23^{\prime} \mathrm{N}, 10^{\circ} 54^{\prime} \mathrm{E}\right)$, 90 to $100 \mathrm{~cm}$ depth.

\section{HAM-1033.}

$4550 \pm 80$

Tirsoid Vertisol, Sta d'Amélioration des Parcours $\left(36^{\circ} 11^{\prime} \mathrm{N}, 10^{\circ} 29^{\prime}\right.$ E) $200 \mathrm{~cm}$ depth.

\section{HAM-1034.}

Palexeroll, $18 \mathrm{~km}$ before Tadjerouine (from Le Kef), $\left(36^{\circ} 5^{\prime} \mathrm{N}, 8^{\circ} 39^{\prime}\right.$ E), $70 \mathrm{~cm}$ depth. 


\section{HAM-1035.}

$8520 \pm 180$

Same profile, fAh, 180 to $210 \mathrm{~cm}$ depth. Samples coll and subm 1981 by $\mathrm{H}$ W Scharpenseel. Comment: results agree with previous soil dates from Tunisia, BONN-433 and -434, HAM-157, -174, and -258, -259 (R, v 12, p 33; v 18, p 282-283; v 19, p 172) regarding three main phases of age ca 2500, 4500-5000, and 8000 BP. HAM-1030 is important, representing soil formation in older pluvial.

Dates from paleosols of deep Tunisian soil profiles located in different climatic zones from perhumid to Saharian.

HAM-1222.

$\mathbf{2 7 9 0} \pm \mathbf{8 0}$

Paleosol 20km W of Nefta $\left(33^{\circ} 48^{\prime} \mathrm{N}, 7^{\circ} 40^{\prime} \mathrm{E}\right)$, exposed in sand dunes, $0.22 \% \mathrm{C}, 0$ to $20 \mathrm{~cm}$ depth.

HAM-1223.

Same profile, $0.11 \% \mathrm{C}, 60$ to $80 \mathrm{~cm}$ depth.

$$
10,260 \pm 120
$$

HAM-1224.

$$
3350 \pm 100
$$

Paleosol, N rim of Chott Djerid, $300 \mathrm{~m} \mathrm{W,} 13 \mathrm{~km}$ to Nefta $\left(33^{\circ} 51^{\prime} \mathrm{N}\right.$, $\left.8^{\circ} 3 \mathrm{l}^{\prime} \mathrm{E}\right), 0.23 \% \mathrm{C}, 32$ to $51 \mathrm{~cm}$ depth.

\section{HAM-1225.}

Same profile, $0.26 \%$ C, 73 to $90 \mathrm{~cm}$ depth.

$$
4330 \pm 90
$$

\section{HAM-1226.}

Same profile, $0.15 \%$ C, 100 to $105 \mathrm{~cm}$ depth.

$$
3980 \pm 90
$$

HAM-1227.

$1950 \pm 60$

Humic layer in exposed gravel terrace, $7 \mathrm{~m}$ towards Chott from HAM$1224,40 \mathrm{~cm}$ depth.

HAM-1229.

$920 \pm 80$

Paleosol, W bank, $300 \mathrm{~m}$ N of streetbridge G P 16, Kebili to Gabès, $62 \mathrm{~km} \mathrm{~W}$ of Gabès $\left(33^{\circ} 48^{\prime} \mathrm{N}, 9^{\circ} 36^{\prime} \mathrm{E}\right)$, marl, $0.14 \% \mathrm{C}, 50$ to $80 \mathrm{~cm}$ depth.

\section{HAM-1233.}

$4810 \pm 80$

Polyphasic steppe soil N of steep bank of Oued Ersifa, E St M C 107, Gabès-Matmata, ca $25 \mathrm{~km}$ to Matmata $\left(33^{\circ} 46^{\prime} \mathrm{N}, 10^{\circ} 03^{\prime} \mathrm{E}\right), 0.22 \% \mathrm{C}, 0$ to $20 \mathrm{~cm}$ depth.

\section{HAM-1234.}

$6260 \pm 160$

Same profile, $0.04 \%$ C, fAh, 160 to $180 \mathrm{~cm}$ depth.

HAM-1235.

$$
5340 \pm 90
$$

Same profile, $0.13 \%$ C, fAh, 220 to $237 \mathrm{~cm}$ depth.

\section{HAM-1236.}

Same profile, $1.15 \% \mathrm{C}$, fAh, 250 to $270 \mathrm{~cm}$ depth.

$$
6420 \pm 130
$$


HAM-1237.

$5200 \pm 160$

Fossil gleysoil, bank of Oued, $5 \mathrm{~km}$ N of Remada, near G P $19\left(32^{\circ} 18^{\prime}\right.$ $\left.\mathrm{N}, 10^{\circ} 20^{\prime} \mathrm{E}\right), 0.04 \% \mathrm{C}, 40$ to $60 \mathrm{~cm}$ depth.

HAM-1239.

$5130 \pm 80$

Same profile, $0.03 \%$ C, fGo, 90 to $120 \mathrm{~cm}$ depth.

HAM-1240.

$7010 \pm 170$

Deep cut with several paleosols in bank of Oued Tatahouine, $\mathrm{N}$ of Foum Tatahouine, near St G P $19\left(32^{\circ} 58^{\prime} \mathrm{N}, 10^{\circ} 28^{\prime} \mathrm{E}\right)$, steppe soil, fAh $0.04 \% \mathrm{C}, 100$ to $130 \mathrm{~cm}$ depth.

HAM-1247.

$13,490 \pm 220$

Same profile, fossil Bv, 750 to $770 \mathrm{~cm}$ depth.

HAM-1248.

$7880 \pm 130$

Cut in Quaternary sediments, $11 \mathrm{~m}$ deep, with calcareous nodules, ca $300 \mathrm{~m}$ SW of Matmata-Toujane St, $3.9 \mathrm{~km}$ from Marhala-Hotel in Matmata $\left(33^{\circ} 35^{\prime} \mathrm{N}, 10^{\circ} 3^{\prime} \mathrm{E}\right), 0.09 \% \mathrm{C}, 160$ to $200 \mathrm{~cm}$ depth.

HAM-1249.

$6570 \pm 200$

Same profile, $0.03 \%$ C, 330 to $380 \mathrm{~cm}$ depth. (Due to very low C concentration slight rejuvenation during handling cannot be excluded).

HAM-1251.

$13,530 \pm 370$

Paleosol, same profile, 430 to $500 \mathrm{~cm}$ depth.

HAM-1261.

$2820 \pm 90$

Sequence of paleosols S of St M 201 Gafsa-Moulares, $18 \mathrm{~km}$ from center of Gafsa, cut of bank Oued Melah $\left(34^{\circ} 31^{\prime} \mathrm{N}, 8^{\circ} 31^{\prime} \mathrm{E}\right), 1.1 \% \mathrm{C}$, epipedon 0 to $15 \mathrm{~cm}$ depth. Following samples are from same profile.

$\begin{array}{ll}\text { HAM-1264. } & 0.39 \% \text { C, } 68 \text { to } 79 \mathrm{~cm} \\ \text { HAM-1265. } & 0.5 \% \text { C, } 93 \text { to } 105 \mathrm{~cm} \\ \text { HAM-1266. } & 0.53 \% \text { C, } 105 \text { to } 131 \mathrm{~cm} \\ \text { HAM-1267. } & 2.25 \% \text { C, } 151 \text { to } 192 \mathrm{~cm} \\ \text { HAM-1268. } & 0.63 \% \text { C, } 192 \text { to } 200 \mathrm{~cm} \\ \text { HAM-1270. } & 0.66 \% \text { C, } 219 \text { to } 251 \mathrm{~cm} \\ \text { HAM-1271. } & 0.56 \% \text { C, } 251 \text { to } 264 \mathrm{~cm} \\ \text { HAM-1273. } & 0.58 \% \text { C, } 287 \text { to } 303 \mathrm{~cm} \\ \text { HAM-1274. } & 0.57 \% \text { C, } 319 \text { to } 339 \mathrm{~cm}\end{array}$

HAM-1275.

$$
\begin{aligned}
& 3910 \pm 80 \\
& 4320 \pm 80 \\
& 2920 \pm 80 \\
& 4490 \pm 80 \\
& 4520 \pm 80 \\
& 4340 \pm 80 \\
& 3900 \pm 80 \\
& 4510 \pm 80 \\
& 5520 \pm 80
\end{aligned}
$$

$117.0 \pm 0.6 \%$ modern

Polyphasic paleosol, W El Frouch, foot of Djebel Chambi, E of road to Serept $\left(35^{\circ} 13^{\prime} \mathrm{N}, 8^{\circ} 13^{\prime} \mathrm{E}\right)$, lower part of "Historique layer," $0.26 \% \mathrm{C}$, 20 to $30 \mathrm{~cm}$ depth. Following samples are from same profile. 
$\begin{array}{llr}\text { HAM-1276. } & \text { fAh, } 0.79 \% \text { C, } 30 \text { to } 80 \mathrm{~cm} & 1980 \pm 70 \\ \text { HAM-1277. } & \text { fAh, } 1.01 \% \text { C, } 80 \text { to } 110 \mathrm{~cm} & 1090 \pm 70 \\ \text { HAM-1278. } & \text { fAh, } 0.70 \% \text { C, } 110 \text { to } 160 \mathrm{~cm} & 5100 \pm 80 \\ \text { HAM-1279. fBt, } 0.55 \% \text { C, } 160 \text { to } 200 \mathrm{~cm} & 7270 \pm 90 \\ \text { HAM-1283. } & & \mathbf{4 0 8 0} \pm \mathbf{8 0}\end{array}$

Red relic soil in crevices of rock, Sta Bordj Chambi, Djebel Chambi $\left(35^{\circ} 15^{\prime} \mathrm{N}, 8^{\circ} 40^{\prime} \mathrm{E}\right), 1300 \mathrm{~m}$ alt, 85 to $200 \mathrm{~cm}$ depth.

HAM-1285.

$1770 \pm 80$

Polyphasic paleosol, ca $800 \mathrm{~m}$ from HAM-1275-79 (35 $15^{\circ}$ N, $8^{\circ} 43^{\prime}$ E), $0.65 \%$ C, 77 to $92 \mathrm{~cm}$ depth. Following samples are from same profile.

$\begin{array}{ll}\text { HAM-1286. } & \text { fAh, } 0.96 \% \text { C, } 92 \text { to } 144 \mathrm{~cm} \\ \text { HAM- } 1287 . & 0.51 \% \text { C, } 144 \text { to } 167 \mathrm{~cm} \\ \text { HAM- } 1289 . & 0.37 \% \text { C, } 192 \text { to } 225 \mathrm{~cm} \\ \text { HAM- } 1290 . & 1.25 \% \text { C, } 225 \text { to } 263 \mathrm{~cm} \\ \text { HAM- } 1292 . & 0.46 \% \text { C, } 287 \text { to } 312 \mathrm{~cm}\end{array}$

HAM-1295. Nem $135^{\circ} 15^{\prime}$ profile.

HAM-1296. $0.62 \% \mathrm{C}, 40$ to $90 \mathrm{~cm}$

HAM-1298. $0.44 \%$ C, 185 to $195 \mathrm{~cm}$

HAM-1 $300 . \quad 0.94 \%$ C, 230 to $240 \mathrm{~cm}$

HAM-1302. $0.56 \%$ C, 333 to $354 \mathrm{~cm}$

HAM-1303. $0.59 \%$ C, 354 to $460 \mathrm{~cm}$

HAM-1304.

Terrace material at foot of profile.

\section{HAM-1305.}

Bank of Oued Bou Hamid, profile $200 \mathrm{~m}$ downstream of HAM-1295$1304,0.58 \% \mathrm{C}, 52$ to $67 \mathrm{~cm}$ depth. Following samples are from same profile.

$$
\begin{aligned}
& 2220 \pm 80 \\
& 2460 \pm 80 \\
& 2700 \pm 80 \\
& 3270 \pm 90 \\
& 2290 \pm 80 \\
& 3070 \pm 90
\end{aligned}
$$

HAM-1306. $0.67 \%$ C, 67 to $105 \mathrm{~cm}$

$$
\begin{array}{r}
3460 \pm 90 \\
3260 \pm 80 \\
3560 \pm 90 \\
6860 \pm 100 \\
14,530 \pm 250
\end{array}
$$$$
\text { HAM-1311. } 0.18 \% \mathrm{C}, 288 \text { to } 321 \mathrm{~cm}
$$ 


\section{HAM-1312.}

Transition to terrace material at foot of profile, $0.03 \% \mathrm{C}, 321$ to $345 \mathrm{~cm}$ (slight rejuvenation during processing of sample due to very low organic $\mathrm{C}$ content cannot be excluded).

HAM-1313.

$\mathbf{9 0 0} \pm 80$

Organic matter in terrace substrate of Oued Bou Hamid, opposite bank of river and HAM-1305-12, 0 to $40 \mathrm{~cm}$ depth. Following samples are from same profile.

HAM-1314. 40 to $75 \mathrm{~cm}$

$$
\begin{aligned}
& 1650 \pm 80 \\
& 2930 \pm 80 \\
& 3110 \pm 80 \\
& 4140 \pm 90 \\
& 4670 \pm 90 \\
& \mathbf{5 2 0} \pm \mathbf{7 0}
\end{aligned}
$$

HAM-1315. 75 to $115 \mathrm{~cm}$

HAM-1316. 115 to $175 \mathrm{~cm}$

HAM-1317. 175 to $225 \mathrm{~cm}$

HAM-1318. 225 to $265 \mathrm{~cm}$

HAM-1319.

Douplex Vertisol, NW Jendouba, N of street to Chamtou, before Satfoura (Oued Bajer) $\left(36^{\circ} 33^{\prime} \mathrm{N}, 8^{\circ} 39^{\prime} \mathrm{E}\right), 1.23 \% \mathrm{C}, 63$ to $100 \mathrm{~cm}$ depth. Following samples are from same profile.

HAM-1319*. HAM-1319 after 6 N HCl hydrolysis

$$
\begin{array}{r}
2740 \pm 80 \\
4840 \pm 80 \\
4170 \pm 100 \\
6760 \pm 90
\end{array}
$$

HAM-1320. $0.34 \%$ C, 116 to $235 \mathrm{~cm}$

HAM-1321. $0.82 \% \mathrm{C}, 235$ to $250 \mathrm{~cm}$

HAM-1323. $0.45 \%$ C, 285 to $324 \mathrm{~cm}$

HAM-1324. Flood deposited young material, 324 to $350 \mathrm{~cm}$. $1940 \pm 80$

HAM-1326.

$$
1660 \pm 60
$$

Polyphasic paleosol, bank of Oued Ogla, ca $2 \mathrm{~km} \mathrm{~W}$ of street G P 17, Le Kef-Tadjerouine, $\mathrm{N}$ bank $\left(36^{\circ} 5^{\prime} \mathrm{N}, 8^{\circ} 38^{\prime} \mathrm{E}\right), 0.74 \%$ C, 0 to $40 \mathrm{~cm}$ depth. Following samples are from same profile.
HAM-1327. $1.15 \% \mathrm{C}, 80$ to $110 \mathrm{~cm}$
$3100 \pm 70$
HAM-1329. $1.38 \%$ C, 146 to $178 \mathrm{~cm}$
$5550 \pm 80$
HAM- $1330 . \quad 0.88 \%$ C, 178 to $210 \mathrm{~cm}$
$4270 \pm 90$

\section{HAM-1333.}

$122.5 \pm 0.7 \%$ modern

Medjerdah alluvium, E Tebourba, S of street Tebourba to Tunis $\left(36^{\circ} 49^{\prime} \mathrm{N}, 9^{\circ} 53^{\prime} \mathrm{E}\right), 0.84 \% \mathrm{C}, 47$ to $64 \mathrm{~cm}$ depth. Following samples are from same profile.
HAM- 1334 . $0.49 \%$ C, 80 to $110 \mathrm{~cm}$
$106.6 \pm 0.5 \%$ modern
HAM-1335. $0.57 \%$ C, 110 to $140 \mathrm{~cm}$
$1730 \pm 80$
HAM-1336. $0.37 \%$ C, 140 to $182 \mathrm{~cm}$
$1240 \pm 80$ 
HAM-1337. $0.47 \% \mathrm{C}, 182$ to $212 \mathrm{~cm}$ $2790 \pm 80$

HAM-1338. $0.75 \%$ C, 212 to $258 \mathrm{~cm}$ $5620 \pm 90$

HAM-1339. $0.37 \%$ C, 252 to $306 \mathrm{~cm}$ $5850 \pm 90$

HAM-1340. $0.25 \%$ C, 306 to $420 \mathrm{~cm}$ $3350 \pm 100$

HАM-1341.

Alluvium of Oued Miliane, $\mathrm{N}$ of street Pont du Fahs-Smindja, $10 \mathrm{~km}$ from Pont de Fahs $\left(36^{\circ} 28^{\prime} \mathrm{N}, 9^{\circ} 56^{\prime} \mathrm{E}\right), 0.40 \%$ C, 130 to $156 \mathrm{~cm}$ depth. Following samples are from same profile.

HAM-1342. $0.78 \% \mathrm{C}, 156$ to $189 \mathrm{~cm}$ $2830 \pm 80$

HAM-1343. $0.80 \% \mathrm{C}, 225$ to $258 \mathrm{~cm}$ $3100 \pm 80$

HAM-1346. $0.19 \% \mathrm{C}, 323$ to $378 \mathrm{~cm}$

$$
3350 \pm 90
$$

HAM-1347.

$100 \%$ of modern

Wadi with paleosols, $\mathrm{N}$ of G P 3, road from Kairouan to Sbeitla, $1300 \mathrm{~m} \mathrm{~W}$ crossing Sbeitla-Kairouan-Tunis $\left(35^{\circ} 36^{\prime} \mathrm{N}, 10^{\circ} 1^{\prime} \mathrm{E}\right)$, entrance to quarry, $0.32 \% \mathrm{C}, 0$ to $20 \mathrm{~cm}$ depth. Following samples are from same profile.

$\begin{array}{ll}\text { HAM-1348. } & 0.33 \% \mathrm{C}, 20 \text { to } 42 \mathrm{~cm} \\ \text { HAM- } 1349 . & 0.32 \% \mathrm{C}, 42 \text { to } 68 \mathrm{~cm} \\ \text { HAM-1350. } & 0.42 \% \mathrm{C}, 68 \text { to } 87 \mathrm{~cm} \\ \text { HAM-1351. } & 0.57 \% \mathrm{C}, 87 \text { to } 115 \mathrm{~cm} \\ \text { HAM-1352. } & 0.81 \% \mathrm{C}, 130 \text { to } 172 \mathrm{~cm}\end{array}$

HAM-1358.

$$
\begin{array}{r}
90 \pm 80 \\
2030 \pm 80 \\
2530 \pm 80 \\
2650 \pm 80 \\
4030 \pm 90 \\
\mathbf{4 9 3 0} \pm \mathbf{9 0}
\end{array}
$$

Cut in alluvium of Oued Melize, S of G P 6, Jendouba to Ghardimaou, near bridge $\left(36^{\circ} 28^{\prime} \mathrm{N}, 8^{\circ} 29^{\prime} \mathrm{E}\right)$, fAh, $0.43 \% \mathrm{C}, 290$ to $340 \mathrm{~cm}$ depth. Following samples are from same profile.

HAM-1360. fAh, $0.36 \%$ C, 404 to $460 \mathrm{~cm}$
HAM-1361. fAh, $0.76 \%$ C, 530 to $580 \mathrm{~cm}$
HAM-1362. fAh, $0.77 \%$ C, 580 to $630 \mathrm{~cm}$
HAM-1363. fAh, $0.60 \%$ C, 630 to $675 \mathrm{~cm}$
HAM-1364. fAh, $0.34 \%$ C, $675+\mathrm{cm}$

HAM-1365. W of G P 1, Tunis-Sfax, km 84 to Sousse, near crossing, Hammamet $\mathrm{R}$ cut $\left(36^{\circ} 25^{\prime} \mathrm{N}, 10^{\circ} 28^{\prime} \mathrm{E}\right), \mathrm{fAh}, 0.19 \% \mathrm{C}, 80$ to $125 \mathrm{~cm}$ depth. Following samples are from same profile.

HAM-1366. $0.19 \% \mathrm{C}, 125$ to $150 \mathrm{~cm}$

$$
\begin{array}{r}
6560 \pm 120 \\
3510 \pm 80 \\
4460 \pm 90 \\
6420 \pm 100 \\
11,020 \pm 130
\end{array}
$$


HAM-1367. $0.67 \%$ C, 150 to $180 \mathrm{~cm}$

HAM-1369.

$1040 \pm 80$

Paleosol in bank of Oued Guilene, E of G P 12, Haffouz to Maktar, near bridge $\left(35^{\circ} 50^{\prime} \mathrm{N}, 9^{\circ} 14^{\prime} \mathrm{E}\right), \mathrm{fAh}, 0.34 \% \mathrm{C}, 40$ to $60 \mathrm{~cm}$.

HAM-1371.

$950 \pm 80$

Paleosol in bank of Oued Hatab, S of G P 4, Maktar to Tebessa $\left(35^{\circ}\right.$ $\left.44^{\prime} \mathrm{N}, 9^{\circ} 3^{\prime} \mathrm{E}\right), 300 \mathrm{~m}$ before crossing with M C $71,100 \mathrm{~m}$ from street, fAhGr, $0.43 \%$ C, 380 to $450 \mathrm{~cm}$. Following samples are from same profile.

$\begin{array}{llr}\text { HAM-1372. } & 0.75 \% \text { C, } 450 \text { to } 497 \mathrm{~cm} & 2530 \pm 70 \\ \text { HAM- } 1373 . & 0.89 \% \text { C, } 497 \text { to } 558 \mathrm{~cm} & 3880 \pm 90 \\ \text { HAM- } 1374 . & 0.59 \% \text { C, } 558 \text { to } 586 \mathrm{~cm} & 3150 \pm 90 \\ \text { HAM-1375. } & 0.35 \% \text { C, } 586 \text { to } 617 \mathrm{~cm} & 3450 \pm 70 \\ \text { HAM- } 1376 . & 0.23 \% \text { C, } 617 \text { to } 650 \mathrm{~cm} & 6420 \pm 100 \\ \text { HAM-1377. } & 0.32 \% \text { C, } 650 \text { to } 690 \mathrm{~cm} & 8080 \pm 130 \\ \text { HAM-1378. } & & \mathbf{1 7 9 0} \pm \mathbf{8 0}\end{array}$

Paleosol in $\mathrm{N}$ bank of Medjerdah $\mathrm{R}, 500 \mathrm{~m} \mathrm{E}$ of bridge Ghardimaou $\left(36^{\circ} 26^{\prime} \mathrm{N}, 8^{\circ} 22^{\prime} \mathrm{E}\right), 0.26 \% \mathrm{C}, 80$ to $120 \mathrm{~cm}$. Following samples are from same profile.

HAM-1379. $0.40 \%$ C, 200 to $240 \mathrm{~cm}$

$1420 \pm 80$

HAM- $1380 . \quad 0.37 \%$ C, 270 to $400 \mathrm{~cm}$

$3820 \pm 80$

HAM-1381. Parallel sample to HAM-1380, but $100 \mathrm{~m} \mathrm{~W}$. 15,000 \pm 210

Samples coll and subm 1979 by H Schiffmann and H U Neue, Ordinariat $\mathrm{f}$ Bodenkunde, Univ Hamburg. Comment: most paleosols indicate origin during Rharbien/Holocene. Only HAM-1247, -1251, -1311, -1364, -1381 reach into late Soltanien/Würmian; HAM-1030, a buried Argid, suggests soil formation during Soltanien pluvial/Würmian high glacial.

In all other paleosol/sediment samples, ratio of organic to carbonate $\mathrm{C}$ was too low for reliable sample of $3 \mathrm{~g}$ organic $\mathrm{C}$ after carbonate destruction. Our efforts were wasted, when we tried to produce datable samples from materials of low organic $\mathrm{C}$ but high carbonate $\mathrm{C}$. The benzene method, requiring 2 to $3 \mathrm{~g} \mathrm{C}$, is obsolete for such samples that contain $<0.1 \%$ organic C.

Results further indicate, that depth of "Historique-layer" as well as of Rharbien/Holocene soils is often underestimated due to extensive fluvial transport during rainy season or torrential floods in ustic and xeric climate. Some anomalous dates, mostly at greater depth (HAM-1249, $-1266,-1277,-1303,-1324,-1330,-1340,-1361,-1374)$ are explainable only by flood deposition of substantial lumps of soil at the flank of the riverbed. Another explanation, animal transport of younger organic matter cannot be excluded. The results confirm our hypothesis, that dating of 
such sediments, eg, for paleoclimatic inf, is not very reliable when based on single or few samples. Layer by layer sampling and dating of 5 to $2 \mathrm{~cm}$ intervals, including $\Delta^{13} \mathrm{C}$, as we are doing now in connection with other sample collns, guarantees max resolution of $\mathrm{C}$ dynamics.

Results of Tunisia series including earlier dates (BONN-433 and -434; HAM-157 to -174, -258 and -259 (R, v 12, p 33; v 18, p 282-283; v 19, p 172) confirm strongly developed soil formation, frequently in several distinguishable phases during Rharbien (Scharpenseel \& Zakosek, 1979; Scharpenseel et al, 1980; Scharpenseel et al, in press). Figures $1 \mathrm{a}$ and $1 \mathrm{~b}$ are histograms of all available ${ }^{14} \mathrm{C}$ dates of Tunisian soil sediment and groundwater samples, indicating time intervals of higher humidity responsible for soil and groundwater formation. Since sampling was done rather randomly all over the country, the number of samples of certain ages may reflect, within limits of total number of samples, frequency of occurrence of different ages.

\section{Sudan}

Thirteen soil profiles of Vertisols from Gezira were measured. Instead of coordinates, which were not taken, sampling loci are according to figure 2. Samples are part of large sample colln including Vertisols of all continents (fig 3).

\section{HAM-1407.}

Profile $1,1 \mathrm{~km} \mathrm{SW}$ of Wad Shawer, 0 to $20 \mathrm{~cm}$ depth. Following samples are from same profile.

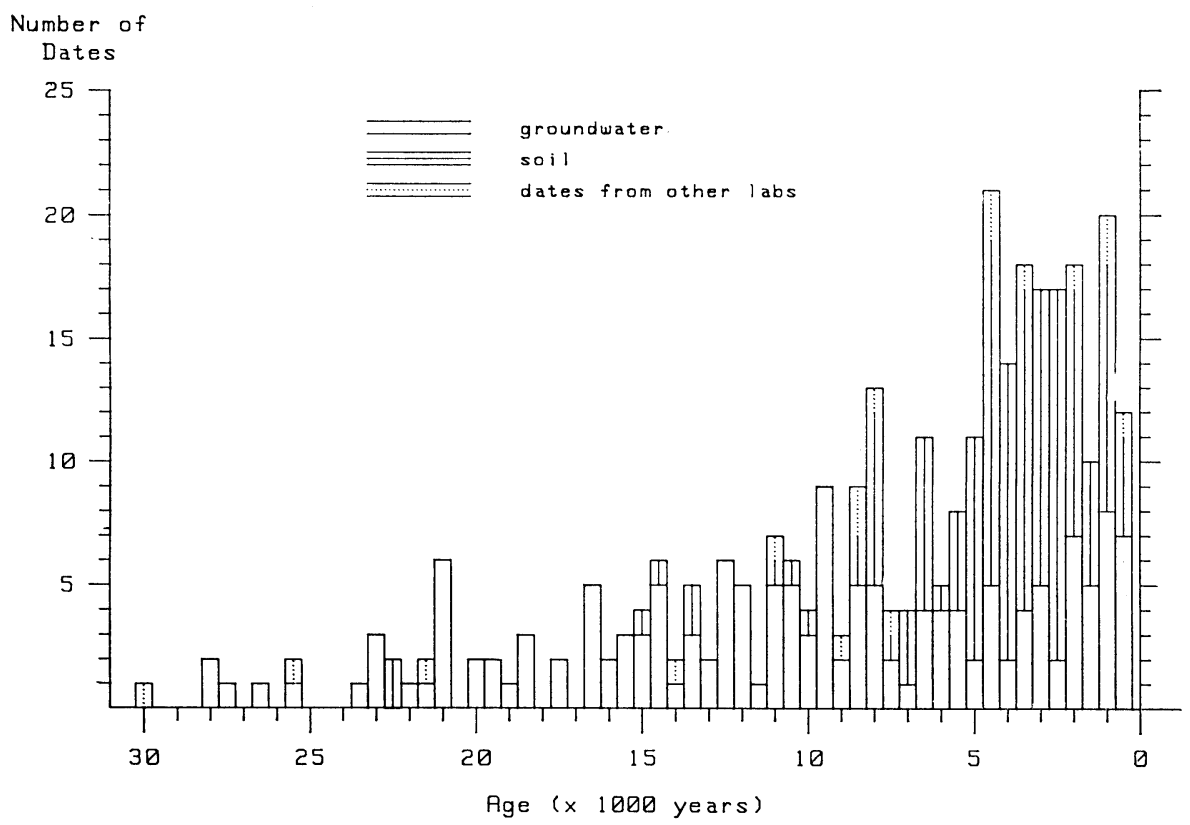

Fig 1a. ${ }^{14} \mathrm{C}$ dates of all available Tunesian groundwater and soil samples; histogram for $500 \mathrm{yr}$ intervals (groundwater dates corrected according to Tamers (1967). 
HAM-1408. 20 to $40 \mathrm{~cm}$

$1720 \pm 80$

HAM-1409. 40 to $60 \mathrm{~cm}$

$1870 \pm 80$

HAM-1410. 60 to $80 \mathrm{~cm}$

$2640 \pm 90$

HAM-1411. 80 to $100 \mathrm{~cm}$

$4660 \pm 90$

HAM-1412. 100 to $120 \mathrm{~cm}$

$4680 \pm 90$

HAM-1413. 120 to $140 \mathrm{~cm}$

$5190 \pm 100$

HAM-1414. 140 to $165 \mathrm{~cm}$

$5580 \pm 100$

HAM-1415. 165 to $185 \mathrm{~cm}$

$3390 \pm 80$

HAM-1416. 185 to $210 \mathrm{~cm}$

$5050 \pm 90$

HAM-1417. 210 to $235 \mathrm{~cm}$

$1900 \pm 80$

HAM-1418. 235 to $270 \mathrm{~cm}$

$3470 \pm 80$

HAM-1419. 270 to $300 \mathrm{~cm}$

$5770 \pm 100$

HAM-1420. 300 to $330 \mathrm{~cm}$

$4780 \pm 90$

HAM-1424.

$1570 \pm 80$

Profile 2, Gezira Selemme Hum Dalik Minor/Wad Mahmoud Major, 0 to $15 \mathrm{~cm}$ depth. Following samples are from same profile.

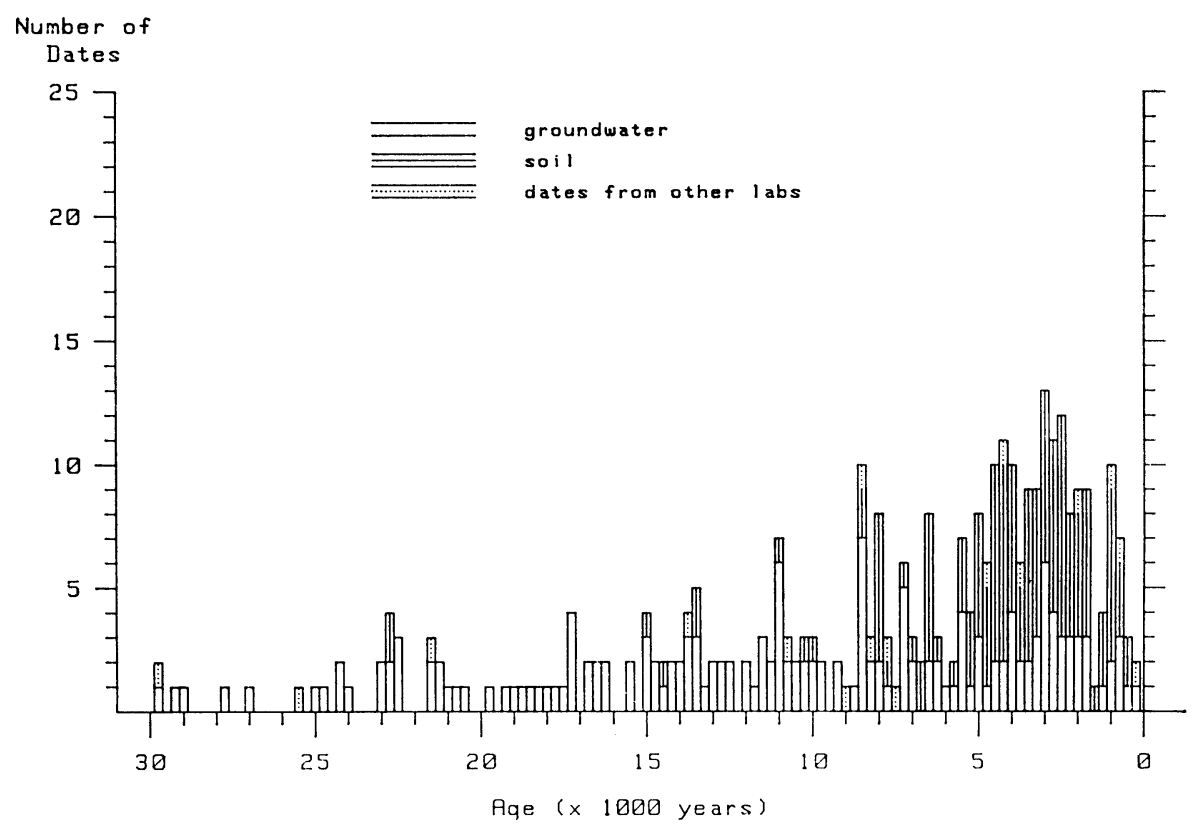

Fig $1 \mathrm{~b} .{ }^{14} \mathrm{C}$ dates of all available Tunesian groundwater and soil samples; histogram for $250 \mathrm{yr}$ intervals (no groundwater date correction). 
HAM-1425. 15 to $40 \mathrm{~cm}$

HAM-1426. 40 to $65 \mathrm{~cm}$

HAM-1427. 65 to $90 \mathrm{~cm}$

HAM-1428. 90 to $120 \mathrm{~cm}$

HAM-1429. 120 to $140 \mathrm{~cm}$

HAM-1430. 140 to $160 \mathrm{~cm}$

HAM-1433. 210 to $245 \mathrm{~cm}$

HAM-1434. 245 to $280 \mathrm{~cm}$

$$
\begin{array}{r}
2210 \pm 80 \\
2040 \pm 80 \\
3240 \pm 80 \\
5330 \pm 90 \\
6250 \pm 100 \\
6290 \pm 90 \\
4690 \pm 80 \\
6300 \pm 90
\end{array}
$$

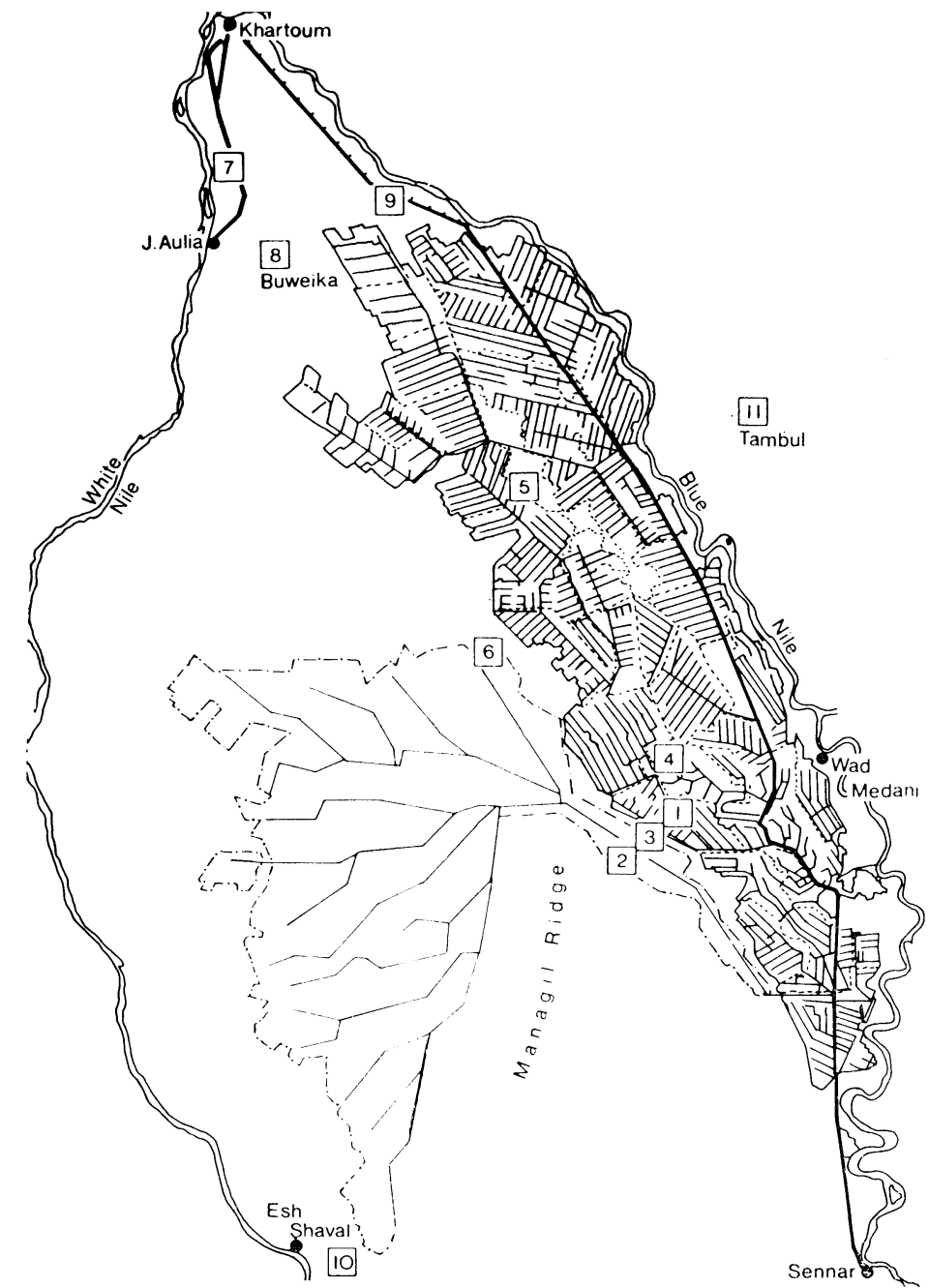

Fig 2. Sites of dated soil profiles in Gezira, Sudan. 
Hamburg University Radiocarbon Dates IV

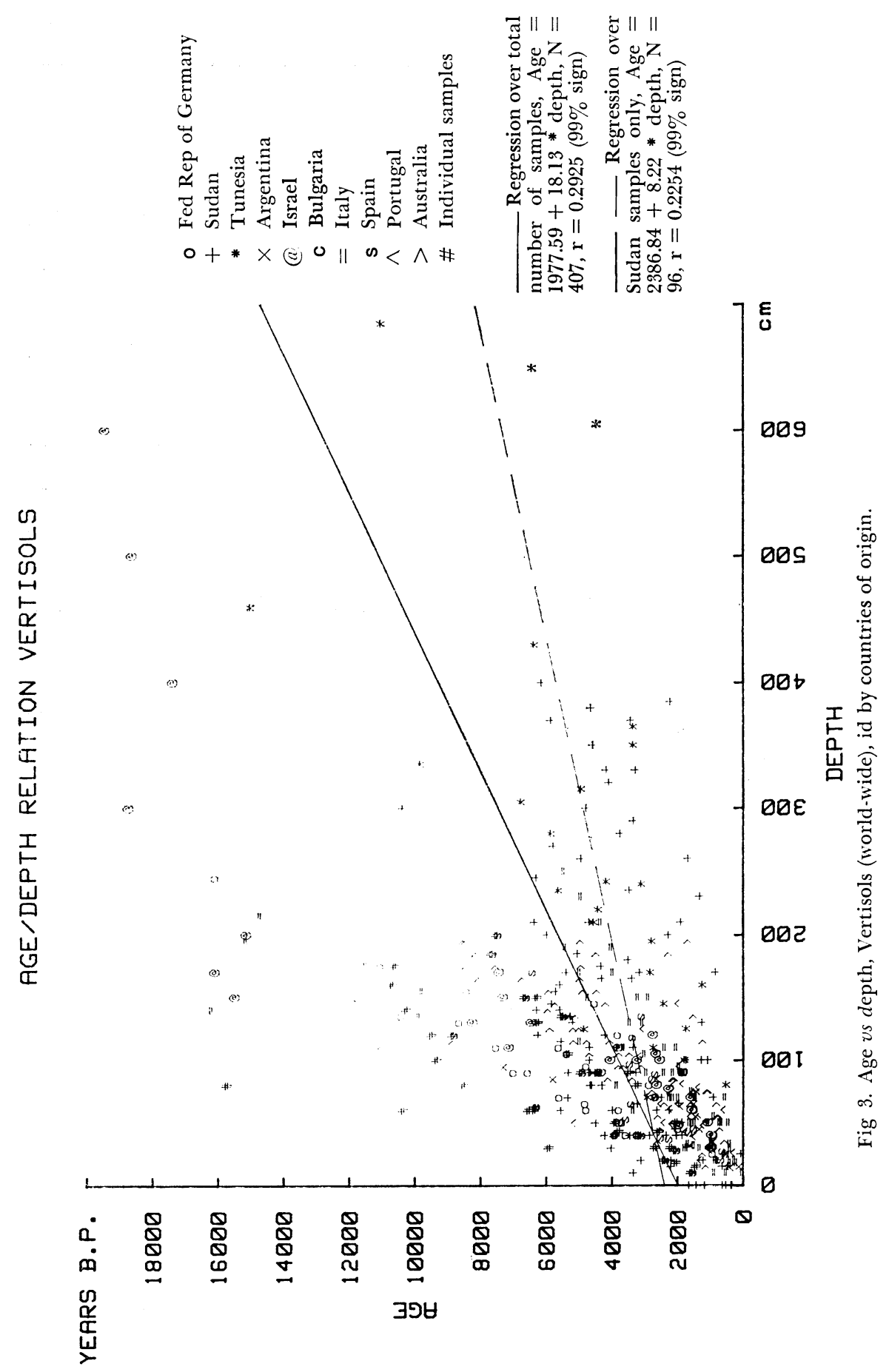


HАM-1440.

$106.5 \pm 1 \%$ modern

Profile 3, Vertisol, $400 \mathrm{~m} \mathrm{~W}$ of Saraf Omeir Minor, 0 to $25 \mathrm{~cm}$ depth. Following samples are from same profile.

HAM-1441. 25 to $45 \mathrm{~cm}$

$$
\begin{array}{r}
70 \pm 70 \\
2070 \pm 80 \\
2500 \pm 120 \\
5270 \pm 140 \\
5710 \pm 100 \\
3500 \pm 90 \\
6360 \pm 130 \\
10,370 \pm 150 \\
5850 \pm 180 \\
6150 \pm 170 \\
540 \pm \mathbf{7 0}
\end{array}
$$

HAM-1442. 45 to $70 \mathrm{~cm}$

HAM-1443. 70 to $100 \mathrm{~cm}$

HAM-1445. 135 to $155 \mathrm{~cm}$

HAM-1446. 155 to $180 \mathrm{~cm}$

HAM-1447. 180 to $210 \mathrm{~cm}$

HAM-1448. 210 to $240 \mathrm{~cm}$

HAM-1451. 300 to $330 \mathrm{~cm}$

HAM-1453. 370 to $400 \mathrm{~cm}$

HAM-1454. 400 to $430 \mathrm{~cm}$

HАM-1455.

Profile 4, Vertisol, Madina Block 15, 0 to $20 \mathrm{~cm}$ depth. Following samples are from same profile.

HAM-1456. 20 to $40 \mathrm{~cm}$

$1230 \pm 80$

HAM-1457. 40 to $60 \mathrm{~cm}$

$2350 \pm 80$

HAM-1458. 60 to $80 \mathrm{~cm}$

$2260 \pm 80$

HAM-1459. 80 to $100 \mathrm{~cm}$

$4620 \pm 90$

HAM-1461. 120 to $140 \mathrm{~cm}$

$4210 \pm 90$

HAM-1463. 165 to $175 \mathrm{~cm}$

$4320 \pm 120$

HAM-1464. 175 to $205 \mathrm{~cm}$

$4390 \pm 120$

HAM-1473.

$\mathbf{3 7 0} \pm \mathbf{8 0}$

Profile 5, Vertisol, $1 \mathrm{~km} \mathrm{~W}$ of Meheiriba, 0 to $20 \mathrm{~cm}$ depth. Following samples are from same profile.

HAM-1474. 20 to $40 \mathrm{~cm}$

$2200 \pm 80$

HAM-1475. 40 to $65 \mathrm{~cm}$

$3460 \pm 90$

HAM-1476. 65 to $90 \mathrm{~cm}$

$3230 \pm 90$

HAM-1477. 90 to $115 \mathrm{~cm}$

$4710 \pm 100$

HAM-1478. 115 to $145 \mathrm{~cm}$

$5550 \pm 100$

HAM-1479. 145 to $170 \mathrm{~cm}$

$5840 \pm 100$

HAM-1480. 170 to $200 \mathrm{~cm}$

$5390 \pm 120$ 
HAM-1481. 200 to $230 \mathrm{~cm}$

HAM-1486. 350 to $380 \mathrm{~cm}$

$4580 \pm 180$

HAM-1487. 380 to $410 \mathrm{~cm}$

$4640 \pm 190$

HAM-1488.

$1180 \pm 80$

Profile 6, Vertisol, Qoz er Ruheid, 0 to $20 \mathrm{~cm}$ depth. Following samples are from same profile.

HAM-1489. 20 to $40 \mathrm{~cm}$

$$
\begin{array}{r}
1240 \pm 80 \\
2050 \pm 80 \\
1280 \pm 80 \\
1270 \pm 100 \\
3160 \pm 80 \\
2280 \pm 110 \\
4940 \pm 250
\end{array}
$$

HAM-1490. 40 to $70 \mathrm{~cm}$

HAM-1492. 100 to $130 \mathrm{~cm}$

HAM-1493. 130 to $170 \mathrm{~cm}$

HAM-1494. 170 to $200 \mathrm{~cm}$

HAM-1495. 200 to $230 \mathrm{~cm}$

HAM-1497. 260 to $300 \mathrm{~cm}$

HAM-1500.

$152.8 \pm 1.3 \%$ modern

Profile 7, Vertisol in terrace of White Nile, SE rim of Tureina, 0 to $10 \mathrm{~cm}$ depth. Following samples are from same profile.

HAM-1501. 10 to $30 \mathrm{~cm}$

$$
\begin{array}{r}
3350 \pm 80 \\
4030 \pm 90 \\
4510 \pm 90 \\
5340 \pm 100 \\
3280 \pm 90 \\
3860 \pm 90
\end{array}
$$

HAM-1502. 30 to $50 \mathrm{~cm}$

HAM-1503. 50 to $70 \mathrm{~cm}$

HAM-1504. 70 to $90 \mathrm{~cm}$

HAM-1505. 90 to $110 \mathrm{~cm}$

HAM-1506. 110 to $140 \mathrm{~cm}$

HAM-1511.

$147.5 \pm 4 \%$ modern

Profile 8 , Vertisol, $1 \mathrm{~km} \mathrm{~W}$ of Buweika, surface sample. Following samples are from same profile.
HAM-1512. 0 to $20 \mathrm{~cm}$
$1660 \pm 80$
HAM-1513. 40 to $60 \mathrm{~cm}$
$2870 \pm 90$
HAM-1514. 60 to $80 \mathrm{~cm}$
$3600 \pm 90$
HAM-1515. 80 to $100 \mathrm{~cm}$
$4310 \pm 100$
HAM-1521.
$860 \pm 80$
Profile 9, Vertisol, $8 \mathrm{~km} \mathrm{~W}$ of Mesou dir Secondary scholl, Laota Block, 0 to $20 \mathrm{~cm}$ depth. Following samples are from same profile.

HAM-1522. 20 to $40 \mathrm{~cm}$

$3120 \pm 90$ 
HAM-1523. 40 to $60 \mathrm{~cm}$

$4230 \pm 250$

HAM-1524. 60 to $80 \mathrm{~cm}$

$5560 \pm 100$

HAM-1530.

$\mathbf{3 2 0} \pm \mathbf{7 0}$

Profile 10, Vertisol, $3 \mathrm{~km} \mathrm{NE}$ of Esh Shaval, 0 to $30 \mathrm{~cm}$ depth. Following samples are from same profile.

HAM-1535. 150 to $180 \mathrm{~cm}$

$$
4530 \pm 80
$$

HAM-1537. 210 to $240 \mathrm{~cm}$

$5930 \pm 120$

HAM-1538. 240 to $285 \mathrm{~cm}$

$5760 \pm 100$

HAM-1539.

$120 \pm 100$

Profile 11, Vertisol, $3 \mathrm{~km} \mathrm{~N}$ of Tamsul, 0 to $25 \mathrm{~cm}$ depth. Following samples are from same profile.

HAM-1540. 25 to $50 \mathrm{~cm}$

$1780 \pm 80$

HAM-1541. 50 to $75 \mathrm{~cm}$

$1930 \pm 80$

HAM-1542. 75 to $100 \mathrm{~cm}$

$3220 \pm 90$

HAM-1543. 100 to $125 \mathrm{~cm}$

$3850 \pm 90$

HAM-1544. 125 to $150 \mathrm{~cm}$

$5260 \pm 100$

HAM-1545. 150 to $175 \mathrm{~cm}$

$5190 \pm 100$

HAM-1546. 175 to $200 \mathrm{~cm}$

$3660 \pm 90$

HAM-1547. 200 to $225 \mathrm{~cm}$

$5320 \pm 110$

\section{HAM-1012.}

$125.4 \pm 1 \%$ modern

Vertisol, sent by Gezira Admin, Hosh series, entic Pellustert, Ghabsaneblock, 0 to $15 \mathrm{~cm}$ depth. Following samples are from same profile.

HAM-1013. 15 to $40 \mathrm{~cm}$

$470 \pm 80$

HAM-1014. 40 to $90 \mathrm{~cm}$

$1970 \pm 80$

HAM-1015. 90 to $135 \mathrm{~cm}$

$3360 \pm 90$

HAM-1016. 135 to $180 \mathrm{~cm}$

$3210 \pm 90$

HAM-1017.

$1390 \pm 70$

Vertisol, Seleimi clay, entic Chromustert, Gezira Research Sta, Wad Medani, fallow plot, 0 to $10 \mathrm{~cm}$ depth. Following samples are from same profile.

HAM-1018. 10 to $30 \mathrm{~cm}$

$$
430 \pm 70
$$

HAM-1020. 50 to $95 \mathrm{~cm}$

$480 \pm 70$

HAM-1021. 95 to $140 \mathrm{~cm}$

$1740 \pm 80$ 
Samples coll and subm 1979 by H Schiffmann and O Khodary, Ordinariat $f$ Bodenkunde, Univ Hamburg and Soil Survey Admin Wad Medani, Sudan. Comment: 13 soil profiles of different depth, serving as cross-sec of Gezira Vertisols, reflect age gradients up to ca 10,000 BP, mostly 5000-6000 BP. This coincides with existing estimates (Greene, 1928; Tothill, 1946), placing origin of Gezira soils in Alleröd time, when allowance is made for slow development to climax of humic-C accumulation as well as for inevitable rejuvenation within cracking zone. Self-mulching, accompanied by above-mentioned crack formation during dry season can bring about inflections of age gradient with depth caused by modern organic matter dropping in deepest holes of cracks (profile 1, 5, 7). If below inflection trend of age $v s$ depth increase continues, it confirms that pedoturbation ends with deepest point of age inflection (profile 2,11). Interruption of age $v s$ depth trend can also be influenced by termite holes and droppings or individual deep roots. Within graph of dated Vertisols of worldwide origin, the correlation of age $v s$ depth is highly significant, and dates of Sudanese Vertisols are located mostly below regression line in younger age $v s$ depth bracket (see fig 3).

\section{Argentina}

Samples dated for genesis of Vertisols in Entre Rios prov, testing extent of vertic soil dynamics (pedoturbation).

HAM-1178.

Soils from rolling pampa near Pergamino $\left(33^{\circ} 40^{\prime} \mathrm{S}, 60^{\circ} 3^{\prime} \mathrm{W}\right)$, vertic Argiudoll, loess, Urquiza series.

HAM-1179.

Typic Argiudoll (34 $\left.13^{\prime} \mathrm{S}, 60^{\circ} 49^{\prime} \mathrm{W}\right)$, loess, Rojas series.

HAM-1180.

$$
1650 \pm 60
$$

Typic Hapludoll ( $\left.34^{\circ} 53^{\prime} \mathrm{S}, 60^{\circ} 25^{\prime} \mathrm{W}\right)$, sandy loess, Segui series.

HAM-1204.

$$
\mathbf{3 0 0} \pm \mathbf{5 0}
$$

Crossing Hwy La Paz to Feliciano street San Gustavo $\left(30^{\circ} 42^{\prime} \mathrm{S}, 59^{\circ}\right.$ $\left.26^{\prime} \mathrm{W}\right)$, argillic Pelludert, $1.3 \% \mathrm{C}, 15$ to $30 \mathrm{~cm}$ depth. Following samples are from same profile.

$$
\begin{array}{ll}
\text { HAM-1205. } & 0.9 \% \text { C, } 30 \text { to } 50 \mathrm{~cm} \\
\text { HAM- } 1206 . & 0.8 \% \text { C, } 45 \text { to } 60 \mathrm{~cm} \\
\text { HAM- } 1207 . & 0.8 \% \text { C, } 60 \text { to } 75 \mathrm{~cm} \\
\text { HAM- } 1208 . & 0.6 \% \text { C, } 75 \text { to } 90 \mathrm{~cm}
\end{array}
$$

HAM-1209.

Profile, Fac Agric, UNL near Paraná $\left(31^{\circ} 50^{\prime} \mathrm{S}, 60^{\circ} 32^{\prime} \mathrm{W}\right.$ ), vertic Pelludert, $1.5 \% \mathrm{C}, 0$ to $17 \mathrm{~cm}$ depth. Following samples are from same profile.

$$
\begin{array}{r}
1120 \pm 60 \\
1650 \pm 80 \\
2880 \pm 80 \\
4440 \pm 110
\end{array}
$$

$106 \pm 0.9 \%$ modern

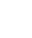

(1)


$\begin{array}{llr}\text { HAM-1210. } & 1.3 \% \mathrm{C}, 17 \text { to } 43 \mathrm{~cm} & 240 \pm 70 \\ \text { HAM-1211. } & 1.3 \% \mathrm{C}, 43 \text { to } 60 \mathrm{~cm} & 440 \pm 70 \\ \text { HAM-1212. } & 0.9 \% \mathrm{C}, 80 \text { to } 100 \mathrm{~cm} & 2180 \pm 90\end{array}$

HAM-1213.

$108 \pm 1 \%$ modern

Fac Agric, UNL near Paraná (31 $\left.50^{\prime} \mathrm{S}, 60^{\circ} 32^{\prime} \mathrm{W}\right)$, Febré 2, vertic Argiudoll, $1.5 \%$ C, 0 to $17 \mathrm{~cm}$ depth.

HAM-1214.

$1120 \pm 60$

$10 \mathrm{~km} \mathrm{SW}$ of General Campos, near main street $\left(31^{\circ} 26^{\prime} \mathrm{S}, 58^{\circ} 25^{\prime} \mathrm{W}\right)$, Yerna 1, argillic Pelludert, $1 \% \mathrm{C}, 15$ to $30 \mathrm{~cm}$ depth. Following samples are from same profile.
HAM-1550. $2.7 \% \mathrm{C}, 0$ to $15 \mathrm{~cm}$
$107 \pm 1 \%$ modern
HAM-1551. $0.8 \%$ C, 30 to $45 \mathrm{~cm}$
$2320 \pm 60$
HAM-1552. $0.7 \% \mathrm{C}, 45$ to $60 \mathrm{~cm}$
$2610 \pm 70$
HAM-1553. $0.6 \% \mathrm{C}, 60$ to $75 \mathrm{~cm}$
$2890 \pm 70$
HAM-1554. $0.4 \%$ C, 75 to $90 \mathrm{~cm}$
$4140 \pm 90$
HAM-1666. $0.2 \%$ C, 90 to $105 \mathrm{~cm}$
$3760 \pm 70$
HAM-1556.
$1910 \pm 60$

Oro Verde 2, $1.25 \mathrm{~km} \mathrm{NW}$ of Experimental Sta INTA, Paraná $\left(31^{\circ}\right.$ $52^{\prime} \mathrm{S}, 60^{\circ} 27^{\prime} \mathrm{W}$ ), Campo anexo, aquic Argiudoll, $0.5 \% \mathrm{C}, 45$ to $65 \mathrm{~cm}$ depth.

HAM-1549.

$1110 \pm 70$

Fac Agric, UNL near Paraná, Febré 2, vertic Argiudoll, 0.8\% C, coord, see HAM-1213, 42 to $58 \mathrm{~cm}$ depth.

Samples coll and subm by S Stephan, Inst f Bodenkunde, Univ Bonn. Comment: soils, investigated by micromorphology, scanning electron microscopy, EDAX and laser-induced mass spectroscopy, and ${ }^{14} \mathrm{C}$ dating show that process of pedoturbation is, at most, very slow and incomplete. ${ }^{14} \mathrm{C}$ age gradients in typical zone of crack formation in real Vertisols is not too pronounced for effective churning and self-mulching system (Stephan et al, 1983). As for most vertic soils, tested soil profiles are rather young.

\section{REFERENCES}

Greene, H, 1928, Soil profile in the eastern Gezira: Jour Agric Sci, v 18, p 527.

Scharpenseel, H W, 1972, Messung der natürlichen C-14 Konzentration in der organischen Substanz von rezenten Böden, eine Zwischenbilanz: Zeitschr Pflanzenernähr Bodenkunde, v 133, p 241-263.

1977, The search for biologically inert and lithogenic carbon in recent organic matter: Soil organic matter studies, Proc, Vienna, IAEA, v, p 193-200.

Scharpenseel, H W and Pietig, F, 1969, Einfache Boden und Wasserdatierung durch Messung der ${ }^{14} \mathrm{C}$ - und Tritium-Konzentration: Geoderma, v 2, p 273-289.

1970, University of Bonn natural radiocarbon measurements III: Radiocarbon, v 12, p 19-39.

Scharpenseel, H W, Pietig, F, and Schiffmann, H, 1976, Hamburg University radiocarbon dates I: Radiocarbon, v 18, p 268-289. 
Scharpenseel, H W and Schiffmann, H, 1977, Hamburg University radiocarbon dates II: Radiocarbon, v 19, p 170-182.

Scharpenseel, H W, Schiffmann, H, Neue, H U, Selmi, S, and Souissi, A, in press, Radiocarbon dating of Tunisian soils, in Maghrebien soil sci conf, 1st, Proc: Tunis, May 1983 , in press.

Scharpenseel, H W and Zakosek, H, 1979, Phasen der Bodenbildung in Tunesien: Zeitschr Geomorph N F supp, v 33, p 118-126.

Scharpenseel, H W, Zakosek, H, Neue, U, and Schiffmann, H, 1980, Search for pedogenic phases during younger Pleistocene and Holocene (Soltanien and Rharbien) of Tunisia, in Stuiver, Minze and Kra, Renee, eds, Internatl radiocarbon conf, 10th, Proc: Radiocarbon, v 22, no. 3, p 879-884.

Stephan, S, Berrier, J, De Petre, A A, Jeanson, C, Kooistra, M J, Scharpenseel, H W, and Schiffmann, H, 1983, Characterization of in situ organic matter constituents in Vertisols from Argentina, using submicroscopic and cytochemical methods-first report: Geoderma, v 30, p 21-34.

Tamers, M A, 1967, Radiocarbon ages of groundwater in an arid zone unconfined aquifer: Am Geophys Union Mono, v 11, p 143-152.

Tothil, J D, 1946, The origin of the Sudan Gezira clay plain: Sudan, Notes and Records, v 27 